\title{
The Influence of Trust, Usability, and Perceived Ease of Use of Financial Technology on Student Behavior Intention of Economic Faculty, UISU Medan
}

\author{
$\underline{\text { Safrida }}^{1}$, Yusrita $^{2}$ \\ 1,2Islamic University of North Sumatera, Medan, Indonesia \\ Email: sal_salahuddin@yahoo.co.id
}

\begin{abstract}
:
The problem formulations of study is: How is the influence of Trust, Usability and Perception of Ease Financial Technology Usages on Student Behavior Intention of Economic Faculty, UISU Medan. The purpose of this study is to analyze the influence of Trust, Usability and Perception of Ease Financial Technology Usages on Student Behavior Intention of Economic Faculty, UISU Medan. The population in this study was 332 students of semester 5 (five). The sample in this study were 77 students of semester 5 (five). By using descriptive data analysis techniques and multiple linear regression analysis, then: The Trust Variables partially have a positive influence on Student Behavior Intention of Economic Faculty, UISU Medan. The Usability variable partially has a positive influence on Student Behavior Intention of Economic Faculty, UISU Medan. The Perceived Ease of Use variable partially has an influence on Student Behavior Intention of Economic Faculty, UISU Medan. The variables of Trust, Usability and Perceived Ease of Use simultaneously had a positive influence on Student Behavior Intention of Economic Faculty, UISU Medan. The value of Determination in this study was 0.522. This shows that $52.2 \%$ of Behavioral Intentions variables can be explained by the variables of Trust, Usability and Perceived Ease of Use, the remaining $47.8 \%$ is influenced by other factors not done in the study.
\end{abstract}

Keywords:

trust; usability; perceived ease of use; behavior intention

\section{Introduction}

Financial Technology (Fintech) deals with companies that use modern innovative technology to shape financial service provision. Fintech is seen as a new market that integrates finance and technology and replaces traditional financial structures with new technology-based processes (Arner, et.al., 2015). The fintech company is a company that offers technology for banking, corporate finance, capital markets, financial data analysis, payments, and personal financial management (Skan, et.al., 2014).

Bank Indonesia Regulation on the implementation of financial technology, Bank Indonesia regulates the registration requirements at Bank Indonesia for organizers conducting payment system activities. The registration obligation is excluded for payment system service providers that have obtained licenses from Bank Indonesia and for providers of financial technology that are under the authority of other authorities.

Leoang et al. (2017) the type of use of Fintech is only student loan services, research findings, Fintech companies in China succeed in their business because they offer loans among students. Students borrow because of difficulties in borrowing at the bank. Many students borrow because of the need to buy mobile phones and laptops Abrahaoetal research results (2016), the use of electronic payment technology using UTAUT, from 605 respondents 
that the use of mobile payments in Brazil is affected by performance expectation, effort expectation, social influence, and perceived risk.

\section{Review of Literature}

Financial Technology (Fintech) is a technology-based service that is currently a trend in the world, both in the form of convenient devices and business (Amalis, Christi \& Barberis, 2016). America and China are the largest countries in Fintech investment. Fintech which is popular in payment transactions are (1) Shopping Vouchers; (2) Points, (3) Deposits, (4) ECurrency or electronic currency and; (5) Transfers.

Bank Indonesia and the Financial Services Authority strongly support technologybased financial services. OJK Regulation Number 77 / POJK.01 / 2016 concerning Information Technology Based Money Lending and Borrowing Services, this regulation regulates the financial services industry that uses Fintech in Indonesia. The term Fintech is more famously used by non-bank startups that provide technology-based financial services.

Azkan, Bindusara \& Hackney (2009) E-Payment Systems as infrastructure in the network and payment methods as a means to exchange monetary values through internet services. Developed countries payment by e-payment becomes common, reflecting the maturity of e-commerce (Effah, 2016).Banking in Indonesia launched e-money transactions from Bank Mandiri, Flazz from BCA Bank, and Tap Cash from Bank BNI. Electronic companies also issue t-cash from Telkomsel, Dompetku from Indosat, and XL Cash from XL Axiata telecommunications services, Go-Pay from PT Gojak Indonesia.

\subsection{Trust $\left(\mathrm{X}_{1}\right)$}

According to Gefen et al (2003) Trust is a major aspect of electronic transactions, because human needs to understand the social environment are very complicated, because one's nature is not always rational or predictable. The research of Chuang et al (2016) modified the Technology Acceptance Model (TAM) by using trust or trust variables in the context of using Fintech. The trust variable is measured by three instruments developed by Chuang et al (2016), namely (1) confidence in service; (2) perception of service quality; and (3) perceived service security

\subsection{Usability $\left(\mathrm{X}_{2}\right)$}

Davis (1989), perceived usefulness is an individual's level of trust in their productivity and performance. If someone feels that the system is useful, then he will use it. Vice versa, if someone believes that something is not useful, then he will not use it. Cuang et al (2016) Indicators of perceived usefulness, namely (1) perceived efficiency; (2) perception of influenceiveness; (3) perceived usefulness in improving performance; and (4) perceived usefulness in information needs.

\subsection{Perceived Ease of Use $\left(\mathbf{X}_{3}\right)$}

According to Davis (1989) perceptions of the ease of use of technology as an individual's belief in the use of a technological system and assume that, the use of technology does not require any effort (free effort) and is easy to understand. Davis (1989) research results, that the perception of ease of use, can explain the reasons for users to use the system and explain the new system can be accepted by users Chuang et al (2016), indicators of perceived ease of use, namely (1) perception of flexibility; (2) perception of ease of interaction; (3) perceived ease of use; and (4) perceived ease of learning separately. Perception contains a 
very broad understanding, concerning internal and external. Various experts have provided various definitions of perception, although in principle they contain the same meaning (Ismail, et al, (2020).

\subsection{Behavior Intention (Y)}

Chau \& $\mathrm{Hu}$ (2001), describe the behavioral tendency to use financial information technology services in financial systems that produce information technology service products. Behavioral intention is measured by one instrument, namely service user intention

\section{Research Method}

This research is a quantitative study, where the population is students of Economic Faculty of UISU semester 5 (five), amounting to 332 students. Sampling technique using Simple Random Sampling, carried out randomly. Sampling was conducted on the population using the Slovin formula (Greener, 2008), then obtained a sample of 77 students.

$$
\begin{aligned}
& \mathrm{X}_{1}=\text { Trust } \\
& \mathrm{X}_{2}=\text { Usability } \\
& \mathrm{X}_{3}=\text { Perception of Ease of Use } \\
& \mathrm{Y}=\text { Intention to Behave }
\end{aligned}
$$

\section{Discussion}

\subsection{Data Quality Test}

\section{a. Data Validity Test}

Validity test is done to find out whether the measuring instrument that has been compiled can be used to measure what is being measured precisely. The validity of an instrument illustrates the level of ability of a measuring instrument used to express something that is the main target of measurement. If the instrument is able to measure the measured variable, it is called valid, and vice versa if it is unable to measure the measured variable, it will be called invalid. Testing the validity of the instrument using the Correlate Bivariate Analyst to find the correlation coefficient of Pearson Product Moment with SPSS. Then compared with the $\mathrm{r}$ table value for $\alpha=0.05$ with degrees of freedom $(\mathrm{dk}=\mathrm{n}-2)$ so that $\mathrm{r}$ table is obtained. For statement items with correlation coefficient ( $r$ count $)>r$ table, the statement items are declared valid.

Because the number of respondents used for the validity test is 77 people, the $r$ table value can be determined from: $\mathrm{dk}=\mathrm{n}-2=77-2=75$

The value of $\mathrm{r}$ table with $\mathrm{dk}=75$ is 0.272 . So, if $\mathrm{r}$ count $>0.272$ then the question item is declared valid.

Table 1. Variable Validity Test Results (X1)

\begin{tabular}{|c|c|c|c|}
\hline Question Number & $\mathbf{r}_{\text {count }}$ & $\mathbf{r}_{\text {table }}$ & Information \\
\hline 1 & 0,591 & 0,272 & Valid \\
\hline 2 & 0,654 & 0,272 & Valid \\
\hline 3 & 0,542 & 0,272 & Valid \\
\hline 4 & 0,681 & 0,272 & Valid \\
\hline 5 & 0,448 & 0,272 & Valid \\
\hline
\end{tabular}


Britain International of Humanties and Social Sciences (BIoHS) Journal ISSN: 2685-3868(Online), 2685-1989(Print)

Vol. 2, No. 1, February 2020, Page: 359-366

\begin{tabular}{|c|c|c|c|}
\hline 6 & 0,569 & 0,272 & Valid \\
\hline 7 & 0,581 & 0,272 & Valid \\
\hline 8 & 0,403 & 0,272 & Valid \\
\hline 9 & 0,635 & 0,272 & Valid \\
\hline 10 & 0,534 & 0,272 & Valid \\
\hline
\end{tabular}

Source: Data processed-2019

Table 2. Variable Validity Test Results (X2)

\begin{tabular}{|c|c|c|c|}
\hline Question Number & $\mathbf{r}_{\text {count }}$ & $\mathbf{r}_{\text {table }}$ & Information \\
\hline 1 & 0,394 & 0,272 & Valid \\
\hline 2 & 0,583 & 0,272 & Valid \\
\hline 3 & 0,541 & 0,272 & Valid \\
\hline 4 & 0,674 & 0,272 & Valid \\
\hline 5 & 0,615 & 0,272 & Valid \\
\hline 6 & 0,623 & 0,272 & Valid \\
\hline 7 & 0,649 & 0,272 & Valid \\
\hline 8 & 0,593 & 0,272 & Valid \\
\hline 9 & 0,742 & 0,272 & Valid \\
\hline 10 & 0,604 & 0,272 & Valid \\
\hline
\end{tabular}

Source: Data processed-2019

Table 3. Variable Validity Test Results (X3)

\begin{tabular}{|c|c|c|c|}
\hline Question Number & $\mathbf{r}_{\text {count }}$ & $\mathbf{r}_{\text {table }}$ & Information \\
\hline 1 & 0,618 & 0,272 & Valid \\
\hline 2 & 0,514 & 0,272 & Valid \\
\hline 3 & 0,625 & 0,272 & Valid \\
\hline 4 & 0,596 & 0,272 & Valid \\
\hline 5 & 0,586 & 0,272 & Valid \\
\hline 6 & 0,465 & 0,272 & Valid \\
\hline 7 & 0,586 & 0,272 & Valid \\
\hline 8 & 0,569 & 0,272 & Valid \\
\hline 9 & 0,486 & 0,272 & Valid \\
\hline 10 & 0,578 & 0,272 & Valid \\
\hline
\end{tabular}

Source: Data processed-2019

Table 4. Variable Validity Test Results (Y)

\begin{tabular}{|c|c|c|c|}
\hline Question Number & $\mathbf{r}_{\text {count }}$ & $\mathbf{r}_{\text {table }}$ & Information \\
\hline 1 & 0,618 & 0,272 & Valid \\
\hline 2 & 0,514 & 0,272 & Valid \\
\hline 3 & 0,625 & 0,272 & Valid \\
\hline 4 & 0,596 & 0,272 & Valid \\
\hline 5 & 0,586 & 0,272 & Valid \\
\hline 6 & 0,465 & 0,272 & Valid \\
\hline 7 & 0,586 & 0,272 & Valid \\
\hline 8 & 0,569 & 0,272 & Valid \\
\hline 9 & 0,486 & 0,272 & Valid \\
\hline 10 & 0,578 & 0,272 & Valid \\
\hline
\end{tabular}

Source: Data processed-2019 
Based on tables 1 to 4 all statements in each variable have a corrected item correlation value ( $\mathrm{r}$ count) greater than $\mathrm{r}$ table.

\section{b. Data Reliability Test}

Instrument reliability illustrates the stability of the measuring instrument used. A measuring instrument is said to have high reliability or can be trusted, if the measuring instrument is stable so that it is dependable and can be used to predict (predictability).

In this study, the reliability test uses the Cronbach Alpha method. Reliability is measured by testing the level of consistency of the measurement results when repeated measurements are made. Reliable or not a data can be seen from the alpha coefficients produced, data approaching 1 (one) can be said to have high reliability. Cronbach Alpha coefficient values close to 1 indicate that the results obtained are more consistent so it is said to have high reliability. A data is said to be accurate if the minimum Cronbach alpha coefficient value is 0.60 . The reliability test in this study used the SPSS program version 25.0.

Table 5. Reliability Test Results

\begin{tabular}{|c|c|c|c|}
\hline Variables & Cronbach's Alpha & N of Items & Reliability Status \\
\hline $\mathrm{X}_{1}$ & 0,748 & 10 & Reliable \\
\hline $\mathrm{X}_{2}$ & 0,805 & 10 & Reliable \\
\hline $\mathrm{X}_{3}$ & 0,733 & 10 & Reliable \\
\hline $\mathrm{Y}$ & 0,904 & 10 & Reliable \\
\hline
\end{tabular}

Source: Data processed-2019

Based on table 5.11 above, it can be seen that the Cronbach alpha value of all variables ranges from 0 to 1 and is more likely to approach number 1 , so that all items in the measurement instrument can be categorized as very reliable.

\section{c. Multicollinearity Test}

Multicollinearity testing is done to see whether the regression model found a correlation between independent variables. If there is a correlation, then there is a problem called multicollinearity. How to detect it is by looking at the value of Variance Inflation Factor (VIF). According to Santoso (2004: 203), in general, if VIF is greater than 5, then the independent variable has a multicollinearity problem with other independent variables. In the SPSS output section Coefficient, all VIF numbers are below 5, this shows there is no multicollinearity, as can be seen in the table below.

Table 6. Multicollinearity Test

\section{Coefficients $^{2}$}

\begin{tabular}{|l|r|r|}
\hline \multirow{2}{*}{ Model } & \multicolumn{2}{|c|}{ Collinearity Statistics } \\
\cline { 2 - 3 } & Tolerance & \multicolumn{1}{|c|}{ VIF } \\
\hline (Constant) & .402 & \\
Trust (X1) & .485 & 2.490 \\
Usability (X2) & .757 & 2.061 \\
Perception of Ease Usage (X3) & 1.321 \\
\hline
\end{tabular}

Source: Out Put SPSS Processed Data-2019 


\subsection{Discussion}

\section{a. Hypothesis Test}

In evaluating this data the writers will test the hypothesis, either partially or simultaneously. Furthermore, to facilitate the evaluation of this data, the authors look for the values needed by using computer software, namely SPSS V.25.00 for windows with the results of the data as follows:

Table 7. Results of the regression test for regression influences

\begin{tabular}{|c|c|c|c|c|c|}
\hline \multirow[t]{2}{*}{ Model } & \multicolumn{2}{|c|}{$\begin{array}{c}\text { Unstandardized } \\
\text { Coefficients }\end{array}$} & $\begin{array}{l}\text { Standardized } \\
\text { Coefficients }\end{array}$ & \multirow[t]{2}{*}{$\mathrm{t}$} & \multirow[t]{2}{*}{ Sig. } \\
\hline & B & Std. Error & Beta & & \\
\hline (Constant) & -4.492 & 5.588 & & -.804 & .424 \\
\hline Trust & .586 & .173 & .432 & 3.383 & .001 \\
\hline Usability & .331 & .151 & .254 & 2.189 & .032 \\
\hline $\begin{array}{l}\text { Perception of } \\
\text { Ease Usage }\end{array}$ & (169. & & 160 & 1.718 & .090 \\
\hline
\end{tabular}

Source: Out Put SPSS Processed Data-2019

Based on Table 7 above can be made a regression equation as follows:

$\mathrm{Y}=-4,492+0,586 \mathrm{X} 1+0,331 \mathrm{X} 2+0,169 \mathrm{X} 3+\varepsilon$

The equation above explained that the coefficient $\mathrm{X}_{1}$ (Trust) has a positive value of 0.586, this shows that the trust variable has a positive influence on Behavioral Intentions. Based on the above equation that the coefficient $\mathrm{X}_{2}$ (Usability) also has a positive value of 0.331. This shows that the Usability variable has a positive influence on Behavior Intentions.

Based on the equation above that the coefficient $\mathrm{X}_{3}$ (Perceived Ease of Use) also has a positive value of 0.169 . This shows that the variable Ease of Use has a positive influence on Behavior Intention.

\section{b. Simultaneous Tests (Test F)}

Table 8. Simultaneous Statistical Test Results

\begin{tabular}{|l|r|r|r|r|r|}
\hline \multicolumn{1}{|c|}{ Model } & Sum of Squares & Df & Mean Square & F & Sig. \\
\hline \multirow{2}{*}{1 Regression } & 582.813 & 3 & 194,271 & 26.558 & $.000^{\mathrm{b}}$ \\
Residual & 533.992 & 73 & 7.315 & & \\
Total & 1116.805 & 76 & & & \\
\hline
\end{tabular}

Source: Out Put SPSS Processed Data-2019

In Table 8 above it can be seen that the $\mathrm{F}$ count value is 26,558 and the significance value is 0,000 . The known $\mathrm{F}$ value with a $95 \%$ confidence level $(\alpha: 0.05)$ is. Therefore the value of F count $>\mathrm{F}$ table $(26.558>3.110)$ then Ho is rejected and accepts Ha the hypothesis in this study that is that Trust, Usability and Perceived Ease of Use simultaneously have a positive and significant influence on Student Behavior Intention of Economic Faculty of UISU Medan. 


\section{c. Partial Tests (t Test)}

1. The Influence of Trust in Behavioral Intentions

Table 9. Partial Test Results of Variable $X_{1}$ against $Y$

\begin{tabular}{|c|r|r|r|r|r|}
\hline Model & \multicolumn{2}{|c|}{$\begin{array}{c}\text { Unstandardized } \\
\text { Coefficients }\end{array}$} & $\begin{array}{c}\text { Standardized } \\
\text { Coefficients }\end{array}$ & \multirow{2}{*}{ T } & \multirow{2}{*}{ Sig. } \\
\cline { 2 - 4 } & \multicolumn{1}{|c|}{ B } & Std. Error & \multicolumn{1}{|c|}{ Beta } & \\
\hline Trust & .586 & .173 & .432 & 3.383 & .001 \\
\hline
\end{tabular}

Source: Out Put SPSS Data Processed-2017

To find out partially the influence of Trust on Behavior Intention can be seen in Table 9 above. Based on the table, the $t$ count value is 3,383 and the significance value is 0.032 . While the value of $t$ table at $95 \%$ confidence level $(\alpha: 0.05)$ is 1,990 Therefore $t$ count $>t$ table $(3,383>1,990)$ then $\mathrm{Ho}$ is rejected and accepts $\mathrm{Ha}$ the hypothesis in this study that the variable Trust is partially positive and significant influence on Students Behavior intention of Economic Faculty UISU Medan.

2. The Influence of Usefulness on Behavioral Intentions

Table 10. Partial Test Results of Variable $\mathrm{X}_{2}$ against $\mathrm{Y}$

\begin{tabular}{|c|r|r|r|r|r|}
\hline Model & \multicolumn{2}{|c|}{$\begin{array}{c}\text { Unstandardized } \\
\text { Coefficients }\end{array}$} & $\begin{array}{c}\text { Standardized } \\
\text { Coefficients }\end{array}$ & \multirow{2}{*}{ Sig. } & \\
\cline { 2 - 5 } & \multicolumn{1}{|c|}{ B } & Std. Error & Beta & & \\
\hline Usability & .331 & .151 & .254 & 2.189 & .032 \\
\hline
\end{tabular}

Source: Out Put SPSS Data Processed-2017

To find out partially the influence of Use on Behavior Intention can be seen in Table 10 above. Based on the table, the value of $t$ count is 2,189 and the significance value is 0,032 . While the value of $t$ table at the $95 \%$ confidence level $(\alpha: 0.05)$ is 1,990 . Therefore, the value of $\mathrm{t}$ count $>\mathrm{t}$ table $(2.189>1.990)$ then $\mathrm{Ha}$ is rejected and accepts the hypothesis Ho in this study that the variable usability partially has a positive influence on the Student Behavior Intention of Economic Faculty UISU Medan.

3. The Influence of Perceived Ease of Use on Behavior Intentions

Table 11. Partial Test Results of Variable X3 against $Y$

\begin{tabular}{|c|r|r|r|r|r|}
\hline \multirow{2}{*}{ Model } & \multicolumn{2}{|c|}{$\begin{array}{c}\text { Unstandardized } \\
\text { Coefficients }\end{array}$} & $\begin{array}{c}\text { Standardized } \\
\text { Coefficients }\end{array}$ & \multirow{2}{*}{$\mathrm{t}$} & \multirow{2}{*}{ Sig. } \\
\cline { 2 - 4 } & \multicolumn{1}{c|}{$\mathrm{B}$} & Std. Error & \multicolumn{1}{c|}{ Beta } & & \\
\hline $\begin{array}{c}\text { Perception of } \\
\text { Ease Usage }\end{array}$ & .169 & .098 & .160 & 1.718 & .090 \\
\hline
\end{tabular}

Source: Out Put SPSS Processed Data-2019

To find out partially the influence of Perceived ease of use on Behavior Intention can be seen in table 12 above. Based on the table, the t count value is 1,718 and the significance value is 0.090 . While the value of $\mathrm{t}$ table at the $95 \%$ confidence level $(\alpha: 0.05)$ is 1,990 . Therefore $\mathrm{t}$ count $<\mathrm{t}$ table $(1.718<1.990)$ then $\mathrm{Ha}$ is rejected and accepts the hypothesis Ho in this study that the variable of Ease of Use partially has a significant positive influence on the Student Behavior Intention of the Economic Faculty of UISU Medan. 


\section{d. Determination Coefficient Test (R2)}

The determinant test is to find out how much influence the independent variable has on the dependent variable. To see the results of the determinant test it can be seen the value of R Square or the coefficient of determination and can be seen below.

Table 12. Model Summary

\begin{tabular}{|l|r|r|r|r|}
\hline Model & R & R Square & Adjusted R Square & \multicolumn{2}{|c|}{$\begin{array}{c}\text { Std. Error of the } \\
\text { Estimate }\end{array}$} \\
\hline 1 & $.722^{\mathrm{a}}$ & .522 & .502 & 2.704 \\
\hline
\end{tabular}

Source: Out Put SPSS Processed Data-2019

The value of $\mathrm{R}$ Square in the table above is 0.522 . This shows that $52.2 \%$ of Behavioral Intentions variables can be explained by the variable Trust, Usability and Perceived ease of use while the remaining $47.8 \%$ was not researched.

\section{Conclusion}

The results of the conclusions prove that Trust, usability and perceived ease of use have a positive influence on Student Behavior Intention of Economic Faculty of UISU Medan. It suggests for students should use Financial Technological Products, which are issued by banks in accordance with Bank Indonesia License.

\section{References}

Amalia, F., Chishti, S., \& Barberis, J. (2016).Book Review : THE FINTECH BOOK : The Financial Technology HandBook Entrepreneurs and Visionaries , 31 (3), 345-348

Abrahao, R. de S, Moriguchi, S.N, \& Andrade, D.F (2016). Intention of Adoption Of Mobile Payment: An Analysis The Light Of The United Theory Of Acceptance And use Of Technology (UTAUT) . RAI Revista De Administracao e Inovacao,13 (3),221-230

Chau dan Hu. 2001. Information Technology Acceptance by Individual Profesionals : A Model Comparison Approach. Decision Science, Vol 32

Chuang,Lui,danKao.2016. The Adoptiono Fintech Service: TAM Perspective. International Journal Of Management And Administrative Science, Vol 3. ISSN : 2225-7225

Davis, Fred. 1989. Perceived Usefulness, Perceived Ease Of Use, And User Acceptance Of Information Technology. MIS Quartely; Vol 13

Effah, J. (2016). Institutional Influence On E-Payment Entrepreneurship A Developing Contry: Enablers and Constraint. Information Technology For Development, 22 (2), 205-219

Gefen, Karahanna dan Straub. 2003. Trusted And TAM in Online Shopping: An Integrated Model. MIS Quartely. Vol. 27

Ismail, et, al. (2020). The Community Perceptions of Poverty in Gampong Ayon, Seulimeum Sub-district, Aceh Besar Regency. (Research Results on March 2017). Budapest International Research and Critics Institute (BIRCI-Journal) : 3(1), 270-275

Skan, Lumb, Masood, dan Conway. 2014. The Boom in Global Fintech Invesment. United Kingdom. Accenture

Santoso,Budi.2012. Pengaruh PerceivedUsefulness,PerceivedEase ofUse,dan Perceived EnjoymentTerhadap PenerimaanTeknologiInformasi.Jurnal StudiAkuntansi Indonesia

Ozkan, S., Bindusara, G.,\&Hackney, R. (2009).Towards Successful e-payment systems:an empirical identification and analysisof critical factors.InEuropean and Mediterranean Conferenceon Information Systems(EMCIS2009)(pp. 1-17). 